\title{
Lean Manufacturing and Sustainability: an integrated view
}

\author{
Barbara Resta ${ }^{1}$, Stefano Dotti ${ }^{1}$, Paolo Gaiardelli ${ }^{1}$, Albachiara Boffelli ${ }^{2}$ \\ 1 CELS - Research Group on Industrial Engineering, Logistics and Service Operations, \\ Department of Management, Information and Production Engineering, Università degli Studi di \\ Bergamo, viale Marconi 5, 24044, Dalmine (BG), Italy \\ 2 Department of Management, Information and Production Engineering, , Università degli \\ Studi di Bergamo, viale Marconi 5, 24044, Dalmine (BG), Italy \\ \{barbar a. rest a; st ef ano. dot t i ; paol o. gai ar del l i ; \\ al bachi ara.bof fel li \}@uni bg. i t
}

\begin{abstract}
Lean Manufacturing has always been seen as a mean to improve efficiency by reducing operations costs, but the recent focus on sustainability and its three pillar (economic, environmental and social) brought new issues to be addressed. In this paper, a new framework that links lean manufacturing with sustainability is proposed and then refined through a cross-sectoral multiple case study. The results highlight the need to align the lean implementation process with the sustainability strategy in order to avoid the negative impacts that lean production could have on the environmental and social components of sustainability.
\end{abstract}

Keywords: Lean Manufacturing; Environmental Sustainability; Social Sustainability; Economic Sustainability; Corporate Social Responsibility (CSR).

\section{$1 \quad$ Introduction}

Since its introduction at Toyota Motor Corporation in 1950's, Lean Manufacturing (LM) has evolved over time. Such a process of evolution has maintained the adherence to Operations Management evolving eras [1], and may be summarised as a focus on quality up to the early 1990s, through quality, cost and delivery (late 1990s), to customer value from 2000 onwards [2]. As sustainability (or Corporate Social Responsibility) began to be an increasingly essential element of Operations Management in the early 2000's [3], scholars started to explore how a traditional LM operations system could be aligned with environmental goals and practices [4], identifying synergies and trade-offs. However, this focus on the environment, while clearly significant, has overshadowed a broader range of sustainability issues [5], which also include the integration of both social and economic aspects, in a systemic and interconnected perspective [6]. In light of the shortcomings of existing literature on the relationship between LM and sustainability, this paper aims to address this gap by shading light on the following research question: How does LM implementation affect

adfa, p. 1, 2011

(C) Springer-Verlag Berlin Heidelberg 2011 
corporate sustainability across its multiple dimensions (economic, environmental and social)?

In the following section, extant literature on LM and its relation with economic, environmental and social sustainability aspects is presented. Then, Section 3 describes the adopted methodology. Results are presented and discussed in Section 4, which precedes the final conclusion, as well as the limitations of the study and future research directions.

\section{Theoretical background}

\section{Sustainability}

Over the last thirty years, the idea of sustainability has become associated with the integration of economic, social and environmental aspects. In this context, the Global Reporting Initiative (GRI) has developed a hierarchical framework [7] consisting of 14 categories, divided into the three pillar of sustainability (as included in Figure 1), to help companies make their operations sustainable.

\section{Lean manufacturing}

As argued by Shah and Ward [8], LM is "an integrated socio-technical system whose main objective is to eliminate waste by concurrently reducing or minimizing supplier, customer, and internal variability". It is a multi-dimensional approach that encompasses a wide variety of management practices, working synergistically and mutually reinforcing, which have been grouped into four complementary bundles [9]: Just-inTime (JIT), Total Quality Management (TQM), Total Preventive Maintenance (TPM), and Human Resource Management (HRM).

Lean manufacturing and economic sustainability

As extensively reviewed by Belekoukias et al. [10], extant literature attributes a wide range of operational benefits to the implementation of LM philosophy and practices, including production cost reduction and speed, quality, dependability and flexibility improvement. Although most of the existing studies suggest that synergies exist among lean practice bundles, only a few scholars translate the operational benefits into economic and financial indicators (as reviewed in [11]), with mixed results. Moreover, when analyzing the relationship between LM and financial performance, the conceptualization of LM is typically narrowly focused on JIT (e.g., [12]), which is part of but not synonymous with LM.

\section{Lean manufacturing and environmental sustainability}

Many authors suggest that companies can use LM as a catalyst to improve environmental practices [13], describing green as the "good public spillover of lean" [14] and a natural extension or stepping stone [15]. Carvalho and Cruz-Machado [16] empower this connection and describe lean and green practices as a synergistic connection of environmental and operations management. However, despite the positive relationships of lean practices and environmental results have been found to exist [17][18], several scholars identify areas where the two approaches cannot be combined and potential conflicts and trade-offs exist [19]. In order to avoid contradictory results and 
non-conclusive results, it is thus fundamental analyzing the relationship between LM and environmental impacts in a systemic and integrated way, avoiding to focus the attention on a specific lean bundle or on a few environmental aspects.

Lean manufacturing and social sustainability

As for the environmental pillar, literature on the relationships between LM and social sustainability does not provide definite results [20]. On the one hand, lean has been argued to have a positive effect on workers' attitudes due to a more varied work, an increased responsible autonomy and a rise in intrinsic motivation [21]. On the other hand, several authors point out the fact that the work is more intense, monotonous and standardized, there is more stress and a loss of autonomy and freedom, with an excessive pressure on people [2]. On the contrary, there seems to be consensus on the positive effects of LM on health and safety in the work environment due to the design of workstations in accordance with ergonomic standards [22], which improves workers' work conditions.

As described in the previous paragraphs, lean operations, when properly defined, have the potential to address a wide range of sustainability issues, included in the conceptual model underlying this research (Figure 1). More empirical research is needed to fully address the benefits of LM for sustainability, which while previously suggested, have never been fully explored across a range of industrial sectors and case studies [23].

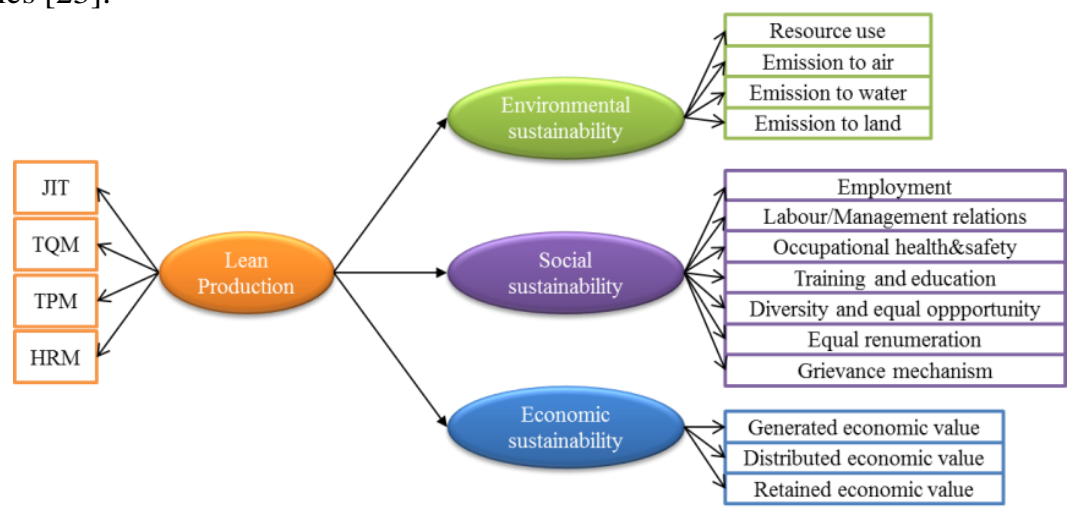

Fig. 1. The conceptual model

\section{$3 \quad$ Research Methodology}

To ground theoretical insights, an inductive case study methodology was employed. The aim of the empirical investigation is to further refine the conceptual model, as well as to shape and develop hypotheses from the collected data [24], regarding the relationship existing between LM and sustainability. In particular, five case studies were theoretically selected, characterised by different level of sustainability and LM implementation. The selected companies were also different in terms of industries and firm sizes. The main information about the sample is reported in Table 1. 
Table 1. Sample companies

\begin{tabular}{|l|l|l|l|}
\hline Company & Industry & $\begin{array}{l}\text { Number of } \\
\text { Employees }\end{array}$ & $\begin{array}{l}\text { Revenues (mio. } \\
\boldsymbol{\epsilon , 2 0 1 4 )}\end{array}$ \\
\hline A & Electric and Automation & $140 \mathrm{~K}$ & 32,806 \\
\hline B & Glass fiber insulation & $182 \mathrm{~K}$ & 41,054 \\
\hline C & Hi-tech navigation systems & 7,500 & 1,834 \\
\hline D & Textile & 385 & 55 \\
\hline E & Automotive & 4,300 & 1,210 \\
\hline
\end{tabular}

For each case, multiple respondents were interviewed. Data were collected through semi-structured interviews as defined in the research protocol, developed around the previously explained conceptual model to guide the research and strengthen reliability [25]. Moreover, direct observations and the analysis of secondary sources, such as company documentation and corporate website, have been used for triangulation to check the internal consistency of data. Data analysis had two main components: within and across case analysis.

\section{$4 \quad$ Results and Discussion}

Company A was the first firm to make the change towards LM in 2006 and several operational benefits have already been observed. The other companies begun to approach lean principles more recently, so they are characterized by a lower lean implementation level. In all the companies the requirement to change came from the top and then was expanded towards the bottom: some companies started to engage employees of all levels from the beginning (case B, C, D) while others (case A, E) involved them gradually after training managers first, with an expansion of the training from the top towards the bottom of the organizational pyramid. The methodologies that constitute the backbone of LM and that are implemented more often are $5 \mathrm{~S}$, TPM, polyvalence and poly-competence principles and Visual Management. The firms that are still in the process of transition towards lean are still testing and making evaluations on "pilot" production or assembly lines so the Yamazumi (organization based on takt-time) and Kamishibai (standard work) principles are not so common in the analyzed sample. Kanban and Heijunka are tools that are worthwhile to be used only if a set of conditions are fulfilled (level of product standardization; type of production system). On the other hand, when the product portfolio is wide, SMED techniques are likely to be implemented. Regardless of the industry, most of the companies are investing in Idea Suggestion tools and Stand Up Meetings, in order to foster cooperation and alignment of efforts and operations, not only amongst colleagues but also with managers from various levels or from other departments/functions. All the companies involved in this study have clearly designed their sustainability goals and they have already implemented social or environmental actions. All the companies have clear idea about what their impact is on the surrounding environment and on the social community they operate in. 
Lean manufacturing and economic sustainability

With a LM system, all the analyzed companies were able to increase the level of output with a less than proportional increase in inputs, meaning that LM is effective in increasing operational efficiency. Moreover, four out of the five analyzed companies implemented LM after the great recession that stroke the world, as a new production paradigm to help them survive in the global competition. On the side of economic results, they were not immediate in most cases: the interviewed companies that have most recently applied the principles have not experienced such benefits yet. The ones that have been able to see this effect present an increase in profits and a fall in working capital mostly thanks to inventory reduction. In the sample there was also a company that had abandoned the path towards lean a few times in the past, due to excessive investment and a poor cost-benefit analysis. Excessive investments are not part of the lean philosophy, so this is a case of misinterpretation of lean principles that leads to failure. Another economic benefit that emerges from the studied cases is the fall in non-quality management costs, which is due to the TQM principle of lean. Overall, despite LM seems to entail a positive economic return for a company, these benefits may not always be immediately measurable and visible. If benefits do not seem to emerge, a firm must first understand whether it is implementing them correctly and coherently to its context. For the sample companies, the main causes of this lack of success are related to problems that arose in the human element during the changeover to lean.

\section{Lean manufacturing and environmental sustainability}

No explicit correlation between these two dimensions was found, except some socalled "green spillovers", meaning the general trend of reducing waste, energy use and resources need. Some environmentally friendly ideas can also be indirectly induced by lean tools; the idea suggestion system has proven to be effective not only for production efficiency matters, which is the purpose for which it is usually implemented, but also for environmental actions. The reason may be that lean and green actions do not ever collide; lean and green seem to be running on two parallel lines that go in the same direction, without being necessarily integrated into a single vision. The main reason for which they do not collide is that they both aim to reduce wastes, even if sometimes they are of different nature. As time goes by and green and lean activities become more deeply-rooted in the company, it may be possible that the two parallel lines they run on become gradually closer, until they eventually become a sole and integrated effort. About the possibility of an increase in transportation due to batch reduction, companies seem to be aware of it, probably also due to the cost, so they tend to prevent it from happening, therefore this risk seems to not be a hazard.

\section{Lean manufacturing and social sustainability}

LM leads to increased personal skills and individual competencies through training programs oriented to all employees, provided in order to achieve poly competence, polyvalence and job rotation. In all cases workers became an important and key asset to the companies. Workers also seemed to react positively to this increased task significance and skill variety, becoming more proactive and not feeling as mere task executors. Despite the positive reaction in the long term, in all cases workers showed 
some initial fear and also opposition to the change. This initial resistance was caused by the need for communication of the principles and underlying reasons of change by the managers. The involvement of professional psychologists was a successful solution to drive the mind-set change. Workers' conditions seem to be improved also on the safety side, especially thanks to methodologies like 5S, Jidoka, TPM and idea suggestion systems. The resulting improvements in ergonomics also entail better working conditions. About the increase in stress level predicted by some scholars, it was found to be mainly related to the workers' personality; in any case, companies seem to be well aware of such risk, and, for this reason, it is kept monitored and addressed when it seems to rise. Not only the condition for workers seems to be improved, but also the one of the managers; thanks to lean principles, they can rely on various and well-rounded opinions, leading to more robust and conscious decision making processes. Such positive impacts were confirmed by the fact that the cases unions did not stand against the change towards a lean system. For example, none of the companies reduced the number of employees. However, the positive impact can occur only if the implementation is correct, well balanced and shared among all the employees. In cases where LM is not implemented properly it may turn out to be extremely harmful. For example, if only kanban and time regulating systems were to be applied with no other precautions, the increase in workers' stress would probably lead to negative social returns.

A summary of the discussion of results is presented in Table 2, where the dimension of the conceptual model have been included.

Table 2. The Effects of LM bundles on the Three Pillars of Sustainability

\begin{tabular}{|c|c|c|c|c|}
\hline & \multicolumn{3}{|c|}{ IMPACTS } \\
\hline & & ECONOMIC & ENVIRONMENTAL & SOCIAL \\
\hline \multirow{4}{*}{ Z } & JIT & $\begin{array}{c}\text { Lower costs due to } \\
\text { lower WIP, stock, lead } \\
\text { times, occupied spac- } \\
\text { es. }\end{array}$ & $\begin{array}{c}\text { Lower waste and more } \\
\text { efficient use of re- } \\
\text { sources. }\end{array}$ & $\begin{array}{l}\text { Higher workplace safety } \\
\text { and ergonomics, lower } \\
\text { accidents and muscular } \\
\text { disorders, higher stress } \\
\text { level for most of the } \\
\text { workers. }\end{array}$ \\
\hline & TQM & $\begin{array}{c}\text { Higher quality (lower } \\
\text { non-quality costs and } \\
\text { higher turnover). }\end{array}$ & $\begin{array}{l}\text { Lower waste, increased } \\
\text { energy consumption. }\end{array}$ & $\begin{array}{c}\text { Reduced risks for work- } \\
\text { ers, higher employee } \\
\text { satisfaction. }\end{array}$ \\
\hline & TPM & $\begin{array}{l}\text { Higher efficiency } \\
\text { (lower costs) and high- } \\
\text { er quality (lower costs } \\
\text { and higher turnover). }\end{array}$ & $\begin{array}{l}\text { Lower waste and lower } \\
\text { resource consumption. }\end{array}$ & $\begin{array}{l}\text { Lower risks for employ- } \\
\text { ees, reduced stress level. }\end{array}$ \\
\hline & HRM & Long-term results. & No evidence found. & $\begin{array}{l}\text { Higher commitment, } \\
\text { satisfaction and lower } \\
\text { stress level. }\end{array}$ \\
\hline
\end{tabular}




\section{Conclusion}

The overall aim of this research was to analyze how the introduction of a LM system in an organization may affect people, environment and corporate profitability.

The scientific contribution of this paper is related to the development of an innovative research model that describes and explains in an integrated and systemic way how the introduction of LM principles and tools contribute to achieve sustainability goals. Managers may use such findings to understand the possibilities given by the integration of lean and sustainable principles, but also that the potential positive return that the implementation of a LM system may bring is not the merely economic, for which such transformation is usually undertaken, but it has also environmental and social impacts. Particularly, the results confirm the strictly positive impact of lean on the economic component. Interestingly, HRM practices are considered as a leverage for maintaining the positive results in the long term because they contribute to build a lean culture in the organisation. On the contrary, the effect on the other two components in some cases is found to be negative. This is due to the lack of alignment between the lean implementation process and the sustainability strategy, or worse to the lack of a sustainability strategy in the first place. In particular, lean and social activities may seem different concepts with different objectives, but by taking a closer look to their components and the results they bring to the production system, they do not seem to be that different. LM gives great value to people and to their ideas and wellbeing, which recalls social sustainability. LM also focuses on the reduction of wastes and scrap items that leads to greatly environmentally friendly benefits. For all these reasons, the concept of the parallel lines that become increasingly closer with time, eventually merging in one single effort, may be generalized for the concept of sustainability as a whole.

The qualitative nature of the investigation is coherent with the state of the art, which is still in an initial phase. In the future, a quantitative survey on a large amount of companies with different levels of lean and sustainability implementation, from "beginners" to extremely advanced systems., should be carried out to test the hypothesize relationships between lean and sustainability.

\section{References}

1. Kleindorfer, P. R., Singhal, K., Wassenhove, L. N.: Sustainable operations management. Prod. Operat. Manag. 14(4), 482-492 (2005)

2. Hines, P., Holweg, M., Rich, N.: Learning to evolve: a review of contemporary lean thinking. Int. J. Operat. Prod. Manag. 24(10), 994-1011 (2004)

3. Angell, L. C., Klassen, R. D.: Integrating environmental issues into the mainstream: an agenda for research in operations management. J. Operat. Manag. 17(5), 575-598 (1999)

4. King, A. A., Lenox, M. J.: Lean and green? An empirical examination of the relationship between lean production and environmental performance. Prod. Operat. Manag. 10(3), 244-256 (2001)

5. Fliedner, G., Majeske, K.: Sustainability: the new lean frontier. Prod. Invent. Manag. J. 46 (1), 6-13 (2010) 
6. Adams, W. M.: The Future of Sustainability: Re-Thinking Environment and Development in the Twenty-First Century. Gland, Switzerland: World Conservation Union, pp. 1-18 (2006).

7. Global Reporting Initiative (GRI) (2015). Sustainability Reporting Guidelines on Economic, Environmental, and Social Performance. GRI: Boston

8. Shah, R., Ward, P. T.: Defining and developing measures of lean production. J. Operat. Manag. 25(4), 785-805 (2007)

9. Shah, R., Ward, P.T.: Lean manufacturing: context, practice bundles, and performance. J. Operat. Manag. 21 (2), 129-149 (2003)

10. Belekoukias, I., Garza-Reyes, J. A., Kumar, V.: The impact of lean methods and tools on the operational performance of manufacturing organisations. Int. J. Prod. Res. 52(18), 5346-5366 (2014)

11. Hofer, C., Eroglu, C., Hofer, A. R. : The effect of lean production on financial performance: The mediating role of inventory leanness. Int. J. Prod. Econ. 138(2), 242-253 (2012)

12. Fullerton, R. R., McWatters, C. S., Fawson, C.: An examination of the relationships between JIT and financial performance. J. Operat. Manag. 21(4), 383-404 (2003)

13. Dües, C. M., Tan, K. H., Lim, M.: Green as the new Lean: how to use Lean practices as a catalyst to greening your supply chain. J. Clean. Prod. 40, 93-100 (2013)

14. King, A. A., Lenox, M. J.: Lean and green? An empirical examination of the relationship between lean production and environmental performance. Prod. Operat. Manag. 10(3), 244-256 (2001)

15. Franchetti, M., Bedal, K., Ulloa, J., Grodek, S.: Lean and green: industrial engineering methods are natural stepping stones to green engineering. Ind. Eng. 41(9), 24-30 (2009).

16. Carvalho, H., Cruz-Machado, V.: Integrating Lean, Agile, Resilience and Green Paradigms in Supply Chain Management. Proceedings of the Third International Conference on Management Science and Engineering Management, pp. 3-14 (2009)

17. Moreira F, Alves A, Sousa R.: Towards Eco-efficient Lean Production Systems. In: Ortiz, A., Franco, R.D., Gasquet, P.G. (eds.) Balanced Automation Systems for Future Manufacturing Networks, vol. 322, pp. 100-108 Springer, Heidelberg (2010)

18. Vinodh, S., Arvind, K.R., Somanaathan, M.: Tools and techniques for enabling sustainability through lean initiatives. Clean Technol. Environ. Policy 13 (3), 469-479 (2011)

19. Rothenberg, S., Pil, F. K., Maxwell, J.: Lean, green, and the quest for superior environmental performance. Prod. Operat. Manag. 10(3), 228-243 (2001)

20. Martínez-Jurado, P. J., Moyano-Fuentes, J.: Lean management, supply chain management and sustainability: a literature review. J. Clean. Prod. 85, 134-150 (2014)

21. De Treville, S., Antonakis, J.: Could lean production job design be intrinsically motivating? Contextual, configurational, and levels-of-analysis issues. J. Operat. Manag. 24(2), 99-123 (2006)

22. Taubitz, M.A.: Lean, green \& safe: integrating safety into the lean, green and sustainability movement. Prof. Saf. 55 (5), 39-46 (2010)

23. Piercy, N., Rich, N.: The relationship between lean operations and sustainable operations. Int. J. Operat. Prod. Manag. 35(2), 282-315 (2015)

24. Voss, C., Tsikriktsis, N., Frolich M.: Case research in operations management. Int. J. Operat. Prod. Manag. 22(2), 195-219 (2002)

25. Yin, R.: Case study research: Design and methods. SAGE Publications, Beverly Hills (1994) 